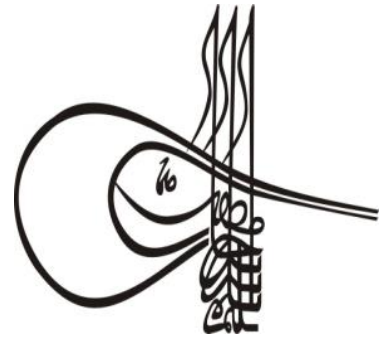

Received/Geliş: 26.06.2019

\section{Turkigh Stuties \\ CUDES 2019}

Volume 14 Issue 5, 2019, p. 323-334

DOI: 10.29228/TurkishStudies. 23420

ISSN: 1308-2140

Skopje/MACEDONIA-Ankara/TURKEY

Research Article / Araştırma Makalesi

Article Info/Makale Bilgisi

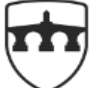

INTERNATIONAL BALKAN UNIVERSITY

EXCELLENCE FOR THE FUTURE IBU.EDU.MK

\Accepted/Kabul: 10.08 .2019

Gor Report Dates/Rapor Tarihleri: Referee 1 (22.07.2019)-Referee 2 (23.07.2019)

This article was checked by iThenticate.

\title{
TOPLUM MÜHENDİSLIGĞINİN BİR ARACI OLARAK EĞİTİM VE 21. YÜZYIL DEMOKRASI MODELLERİ
}

\author{
Elif GENÇKAL EROLER*
}

\begin{abstract}
öz
Küreselleşmeye rağmen milliyetçilik günümüzde etkisini halen sürdürerek, ulus kimliği inşasında etkili olan bir ideolojidir. Söz konusu ulus inşası iktidarların hegemonyalarını yeniden üretme noktasında etkili bir aygıt olarak kullandıkları ve denetim altında tuttukları eğitim sistemi üzerinden izlenebilir. Eğitim politikaları, siyasal iktidarın gücünü yeniden üretme ve bu doğrultuda ulus kimliği inşasında etkili bir araç olduğundan, bir ülkede demokrasinin durumu eğitim politikalarına bakarak anlaşılabilir. Zira eğitim politikaları iktidarların elinde, onların demokrasi ile kurduğu ilişki ile uyumlu olarak şekillenir. Özellikle de ders kitaplarında yer alan anlatı, dönemin siyasal söyleminin adeta bir kopyasıdır. Tarihsel eğilime bakarsak, 19. Yüzyılda ve 20. yüzyılın başında "çoğunluğun yönetimi" olarak tanımlanan demokrasinin, 21. yüzyıldaki tanımını kısaca "alt kimliklere saygı" şeklinde ifade etmek mümkündür. Yani 20.yüzyıl klasik demokrasisinin çoğunlukçu demokrasi modeline, 21. yüzyıl çağdaş demokrasisinin ise çoğulcu modele dayandığı söylenebilir. 21.yüzyılda çoğulculuğu esas alan çağdaş demokrasi anlayışının 20.yüzyılın çoğunlukçu klasik demokrasi anlayışından üstün olduğu açık olsa da, 21. yüzyılda dünyada paradoksal biçimde yeni bir otoriterliğin yükseldiği görülür. Söz konusu otoriterlik, çoğunlukçu demokrasi modelinin yozlaşması sonucunda ortaya çıkan, çoğunluğun oyunu alarak iktidara gelmeyi tüm topluma hakim olmak sayan bir yönetim anlayışıdır. Bu anlayış, muhalefeti hoş karşılamayan, dahası bunu "milli irade" karşıtlığı sayarak "biz" sınırlarını daraltan ve "öteki" sınırlarını genişleten bir otoriter-popülist eğilime işaret eder. Söz konusu yeni otoriterlik, 20. Yüzyıl milliyetçi eğitim anlayışının yeniden yükselmesi anlamında eğitim politikaları üzerinden izlenebilir.
\end{abstract}


Anahtar Kelimeler: Eğitim, Milliyetçilik, Ulus Kimlik, Hegemonya, İlliberal Demokrasi, Çoğulcu Demokrasi, Çoğunlukçu Demokrasi

\title{
EDUCATION AS A TOOL OF SOCIAL ENGINEERING AND DEMOCRACY MODELS IN 21ST CENTURY
}

\begin{abstract}
In spite of globalization, nationalism is an ideology that is still influential in the construction of national identity. This nation-building can be traced through the education system that is used and controlled by governments as a powerful device for the reproduction of their hegemonia. Since education is an effective tool in the reproduction of political power and in the construction of national identity in this direction, the state of democracy in a country can be understood by looking at education policies. Because education policies are shaped in the hands of the governments in accordance with their relationship with democracy. Especially the narrative in the textbooks is a copy of the political discourse of the period. If we look at the historical trend, it is possible to express the definition of democracy in the 19th century and early 20 th century as the rule of the majority, in the 21 th century as the form of respect for sub-identities. In other words, it can be said that 20th century classical democracy is based on the majority model of democracy and 21st century contemporary democracy is based on the pluralist model. Although it is clear that the contemporary understanding of democracy, which is based on pluralism in the 21 st century, is superior to that of the majority classical democracy in the 20th century, it is seen that a new authoritarianism has risen paradoxically in the world in the 21 st century. This new authoritarianism's conception of governance has emerges emerged as a result of the degeneration of the majority model of democracy. This understanding points to an authoritarian-populist tendency that does not welcome the opposition, and narrows the "us" borders while enlarging the "other" in national identity. This new authoritarianism can be traced through educational policies in the sense of the rise of the 20th century nationalist education.
\end{abstract}

\section{STRUCTURED ABSTRACT}

Nationalism is a very influential force in the modern world since late eighteen century. Most nation-states have had social engineering projects for creating modern homogeneous entity. Despite of the different unique dynamics belong to each case, both the political and cultural criteria play role in the nation-building process. In this process, individuals are turned to be citizens who are constructed according to ideological and political needs of the nation-states. For homogenizing the population and turn individuals into citizens, nation-states have used coercive power like migration and population exchange. However, some institutions like education are served more effectively than coercive techniques to make the people learn and internalize national identity. One of the most important tools of the state to disseminate the new national identity is formal education. Education enables the state to offer 
the population a sense of belonging to the newly created nation. As an institution where nationalist discourse is reproduced and national identity is internalized through socialization, schools are important place to understand not only the ideal citizenship profile of a nation-state, but also the "others" of the specific governments.

Educational system of a society is important in designing life view and the type of human wanted to be raised in this society. School books as basic materials of educational system and declared role of education expressed by political elites, party and government programs are also important to analyze in order to get knowledge about the national identity wanted to be created by the state. The effective transmittance of the information of a society through education from one generation to another increased the importance given to the education in modern societies. The school was started to be used as the ideological tool of the modern state.

In this study, the formulation of modernists which express that nations are constructed by nationalism will be followed. Modernist thinkers do not see the nation as a fundamental or unchangeable entity, but they argue that the nation is invented by nationalism in a process of economic and technological developments. The view that the nationalism created the nation, rather than the opposite is one of the basic views of modernists. They claim that nation is a product of nationalism that occurred as a useful ideology which could accommodate the demands of the modern era. Therefore, as an invention of nationalism, nation-states did not existed from the beginning and occurred with the modernization. As a result, modernist thinkers do not see the nation as a fundamental or unchangeable entity, but they argue that the nation is invented by nationalism in a process of economic and technological developments.

This study claims that political ideology and level of democracy of a country can be observed from her educational policies. The construction of nation and national identity can be traced through the education system that has been nurturing nationalism and controling and using by governments as an effective device at reproducing of their hegemony. Because education policies are shaped in the hands of the governments in accordance with their relationship with democracy. Especially the narrative in the textbooks is a copy of the political discourse of the period. If we look at the historical trend, it is possible to express the definition of democracy in the 19th century and early 20th century as the rule of the majority, in the 21 th century as the form of respect for sub-identities. In other words, it can be said that 20th century classical democracy is based on the majority model of democracy and 21 st century contemporary democracy is based on the pluralist model. Although it is clear that the contemporary understanding of democracy, which is based on pluralism in the 21 st century, is superior to that of the majority classical democracy in the 20th century, it is seen that a new authoritarianism has risen paradoxically in the world in the 21 st century. This new authoritarianism's conception of governance has emerges emerged as a result of the degeneration of the majority model of democracy.

Such a strong centralized leadership based on electoral consent weakens the separation of power and institutional checks and balances. 
In this context, being the winner of elections and representing the "national will" is attributed a kind of metaphysical meaning which is over any law, international norm or universal value. Those who criticizing the elected government are declared as illegitimate people opposing "national will". This political situation is conceptualized by some intellectuals as "elective dictatorship" or "illiberal democracy". Actually the conceptualizations like "illiberal democracy", "elective dictatorship", "new authoritarianism" refer to a global authoritarian-populist trend. In these cases, an illiberal democracy where free elections take place but liberal values and impersonal state institutions are getting weakened.

This understanding points to an authoritarian-populist tendency that does not welcome the opposition, and narrows the "us" borders while enlarging the "other" in national identity. This new authoritarianism can be traced through educational policies in the sense of the rise of the 20th century nationalist and militarist education policies.

Keywords: Education, Nationalism, National Identity, Hegemony, Illiberal Democracy, Pluralist Democracy, Majoritarian Democracy

\section{Giriş}

İçinde bulunduğumuz küreselleşme çağının ulus-devletlerin krizi ve milliyetçilik çağının sonu anlamına geldiği tartışmaları çokça yapılıyor. Delanty ve O'Mahoney'e göre ulus-devlet ve uluskimliğin sonundan ziyade, küreselleşme şartlarında ulus-devletin geçirdiği dönüşüme bakmak gerekir (Delanty and O'Mahony, 2002, s.169-170). Gerçekten de ekonomik etkinlik ve düzenlemelerin giderek arttığı, siyasetin ulus-üstü ve ulus-altı düzeylerde icra edildiği bir dünyada milletin ötesinde farklı aidiyet duyguları ortaya çıkıyor, fakat bu ulus-devletlerin sonu veya ulus aidiyetinin yerinin küresel bir kimlik aldığ 1 anlamına gelmiyor. Hatta tam tersine, küresel ağlar aracılığıyla "yabancı" kültürlerle yakın temas çoğu zaman milli kimliği ayırt eden özelliklere dair farklılıkta ve koruma kararlığında artışa yol açıyor, azalmaya değil (Özkırımlı, 2010, s.121). Küreselleşmenin sonucunda ortaya çıkan kitlesel göçler, teknolojik dönüşüm, milli hakimiyetin zayıflaması gibi gelişmeler pek çok insanda bir güvenlik tehdidi algısı yaratarak ulus-kimliklerine daha fazla sarılmaları sonucunu doğuruyor. Bunun ötesinde, küreselleşme devletlere, vatandaşlarına tek bir kültürü dayatma imkanlarını da azaltarak devlet içindeki yerelliklere fırsat tanır, böylece azınlık milliyetçiliklerinin ortaya çıkmasına zemin hazırlar. Robertson, küreselleşmenin "yerellik"in yeniden kurgulanmasını, bir anlamda yeniden üretimin içerdiğini tespit eder ve küresel ile yerel olanın iç içe geçmişliğini ve eş zamanlı olarak hüküm sürdügünü vurgulayan küyerelleşme kavramını kullanır. Robertson, küreselleşmenin yerel kimliklerin türdeşleşmesi anlamına gelmediğini, tam tersine yerel olanın küresel olduğunu savunur (Robertson, 1995, s. 30-35). Küreselleşme süreciyle birlikte dünyanın değiştiği ve ulus-devletlerin de bu süreçte bir dizi sorunla karş1 karşıya kaldıkları bir gerçek. Fakat küreselleşme koşullarının doğurduğu şey ulus-devletlerin aşılması değil, ulus-devletlerin ve ulusal kimliklerin dönüşümüdür. $\mathrm{Bu}$ anlamda, küreselleşme çağında milliyetçilik ideolojisinin etkisi değişmekle birlikte devam etmektedir.

Milliyetçilik çağında ortaya çıkan modern vatandaşlık, devletin var olan sosyal düzeni yeniden üretmesinin yöntemi olan ulus-inşa süreci ile doğrudan ilişkilidir. Dili, kültürü, eğitimi düzenleme gücünü elinde bulunduran iktidar olarak ulus-devlet, ulusal kimliği de şekillendirme gücünü elinde tutar. Ulus-kimliği, biz/onlar ayrımında güç alarak dışlamaları içerir, yani "modern yurttaşlık kavramı milliyetçi ideolojiyi destekler şekilde, bireylerin "benzerlik" temelinde aynı ulusal kültüre aidiyetlerini ve/veya "farklılık" temelinde "yabancıları"” bu ulusal kültürden dışlanmalarını belirleyen bir kurumdur" (Brubaker, 1992, s.39-45). Aslında doğası gereği tüm kimlikler "öteki” yaratmaya eğilimlidir, dolayısıyla ötekinin olmadığı bir toplum düşünmek zordur. İlhan Tekeli’nin de belirttiği 
gibi, bu kavram üstünlük ima etmeyen farklılıklar üzerine kurulduğunda sorun olmayacaktır, yani "ötekinin olmadığı bir toplum arayışı anlamsızdır, anlamlı olan arayış, bir toplumda çatışma yaratmayan, dışlayıcı olmayan 'öteki' anlayışlarının nasıl kurulacağıdır”' (Tekeli, 2014, s.3). Fakat milli kimlikler çoğunlukla kültürel çeşitlilik ve farklılıkları gözetmekten çok, ulusal birliği sağlamaya yönelik oldukları için "vatandaşlarından ülkenin resmi tarihine, milli ülküsüne, mitoslarına inanmasını, resmi kimliği bir üniforma gibi övünç ve inanç ile taşımasını bekliyor" (Güvenç, 2014, s. 26).

Ulus-devletlerin tek tip ve kültürel çeşitlilikten yoksun bir toplum yaratma isteğine rağmen, homojen bir toplum yaratma isteği ütopyadır. Toplumlar hiçbir zaman homojen olamayacağından toplumsal kimliklerin de çok farklı boyutları vardır. Milletler ve milliyetçilik modern çağın siyasi, ekonomik ve toplumsal koşullarının bir ürünü olarak ortaya çıkmalarına rağmen tamamıyla modern çağ ile de özdeşleştirilemezler, zira zaman içinde kendine ait bağımsız bir gerçeklik de kazanmışlardır. Modern sonrası zamanlarda ve küreselleşen dünyada milliyetçiliğin halen varlığını sürdürmesi bu sebeptendir, dolayısıyla post-modern bir çağa girilmesiyle veya küreselleşme süreçleriyle yok olması beklenmemelidir. Milliyetçilik elitlerin çıkar kavgalarında kullandıkları bir araçtan ibaret değildir, çok sayıda ve çeşitli boyutlarda farklı milliyetçilikler tarif etmek mümkündür. Siyasi, kültürel ve ekonomik çeşitli durumlara göre egemen olan milliyetçilik projeleri zaman içinde farklılık gösterir. Bu durumda milliyetçilik, resmi ideolojiye indirgenemez, çünkü toplumdaki bireyler, elitlerin ürettikleri politikaların pasif alıcıları değildirler. Tam tersine, bireyler, üretilen resmi ideolojiyi olduğu gibi kabul etmez, kendi dünya görüşleri, düşünceleri ve beklentilerine göre evirirler. Kuşkusuz, toplum ve içinde yaşayan toplumsal sınıflar, gruplar, kültürler ve bireyler sadece yönetici sınıflar ve devlet içindeki karar verici ve güç sahibi elitler tarafından yukarıdan aşağıya şekillendirilemezler; toplum bir bütün olarak, ne kadar güçlü olurlarda olsunlar, bu güçlerin yanı sıra ve bu güçlere karşı toplumsal güçlerin verdikleri cevaplarla oluşur (Özdoğan vd., 2009, s.19).

Özkırımlı, yaptığı resmi ve gayri-resmi milliyetçilik ayrımıyla söz konusu aşağıdan ve yukarıdan süreçlere işaret eder. Buna göre, resmi milliyetçiliğin tek amacı homojen ve uyumlu bir toplum yaratmak iken; gayriresmi milliyetçilik gündelik hayatın içinde yeşeren, deneyimlere ve koşullara bağlı, daha pratik ve duygusal, yereli referans alan, resmi ideolojinin uzanamadığı yerlere ulaşan karakteriyle bu hedefe ulaşmanın imkansızlığını ifade eder (Özkırımlı, 2009, s. 708-709). Buna göre, resmi milliyetçilik sınırları çizer, gayriresmi milliyetçilikler ise bu sınırları sürekli zorlar, resmi milliyetçiliği değişmeye uyum sağlamaya iter. Bu da resmi ideolojinin belirli bir zaman dilimi içerisinde "evrilmesine" yol açacaktır. Bu durumda milliyetçiliği ve ulus-inşasını anlamak için yapılması gereken, resmi milliyetçilik ile gayri-resmi milliyetçiliği, dolayısıyla yukarıdan aşağıya makro milliyetçilikler ve aşağıdan yukarıya mikro-milliyetçilikleri birlikte değerlendirmektir.

\section{Yapılanmacı/Modernist Yaklaşıma Göre Milliyetçilik-Eğitim İlişsisi}

Bireylerin tek bir doğuştan verili tek bir kimlikleri olduğunu, bu kimliğin de toplumsal değişimden etkilenmediğini savunan özcü bakış açısı, bireyler gibi kültürlerin de toplumsal dönüşümden etkilenmeyen, ezelden ebede var olan olgular olduğunu iddia eder. Buradan hareketle toplumsal aktörleri, etkin değil edilgin yapıda gören bu bakış açısı, ulusların ezelden beri var olduğu düşüncesini savunur. Bu çalışma özcü bakış açısının aksine, ulusların ezelden beri var olduğu bir diğer deyişle verili olduğu düşüncesinin ulus-inşa sürecinde öğretilen bir durum olduğunu iddia eder. Söz konusu öğretmenin de yolu buna uygun bir eğitim sistemi kurgulamaktır.

$\mathrm{Bu}$ çalışmada takip edilecek düşünce sistemi, kültürleri ve milletleri böylesine verili ve değişmez kabul eden özcü yaklaşımı reddeden, tersine toplumsal aktörleri kültürle ilişki içinde ele alan yapılanmacı yaklaşımdır. Buna göre, kültür kendinde bir olgu değildir, aktörlerin yaratıcı bir biçimde inşa etmesiyle oluşur. Toplumsal kültürü oluşturan gelenek, dil, din gibi öğelere yüklenen anlamlar ve verilen değerler, değişen koşullara göre sürekli yeniden tanımlanır. Bu durumda toplumsal koşullar değiştikçe değerler sistemi de değişecektir. Yani milletlerin üyeliği ve ulus kimliği verili değildir, 
değişiklik gösterebilir. Değişen toplumsal koşullar eski toplumsal örgütlenmeyi yetersiz ve geçersiz kıldığı noktada, milleti kurgulamak ve hayal etmek işlevsel hale gelir (Gençkal Eroler, 2019, s. 24).

Yapılanmac1/ modernist düşünürlerin ortak noktası milletin ve milliyetçiliğin ortaya çıkmasını modernizm ile ilişkilendirmeleri olmakla birlikte, her biri farklı unsurlara dikkat çekmişlerdir. Örneğin Gellner, milliyetçilik ile sanayi toplumu arasındaki ilişkiye dikkat çekerek milliyetçiliğin işlevinin, sanayileşme ya da daha geniş anlamıyla modernleşmenin geleneksel tarım toplumlarında büyük yıkımlara yol açması sonucunda kentlere yığılan milyonlarca insanın ortak bir kültürel zemine oturtulması için ihtiyaç duyulan yeni siyasi-idari düzenin oluşturulması olduğunu savunur. Bu düzen içinde gerekli olan kültürel türdeşliğin ise eğitim sistemi ile sağlandığına inanır. Toplum tasarımcıları, tarım kültürünün pek çok farklı alt kültüründen gelen yığınlara standartlaştırıcı eğitim sistemini dayatarak onlara yüksek kültür empoze eder, bu da modern toplumun kendini yeniden üretim biçimi ile yakından ilişkilidir, zira, "meşru eğitimin tekelini ele geçirmek, artık meşru şiddetin tekelini ele geçirmekten daha önemli ve belirleyici olmuştur" (Gellner, 2013, s.112) Bir diğer yapılanmacı/ modernist düşünür Benedict Anderson, bir kültürel yapım olduğunu iddia ettiği milliyetçiliği açıklayabilmek için onu ideolojilerle birlikte düşünmek yerine din ve akrabalık gibi olgularla bir arada düşünmek gerektiğini savunur. Milletin ihtiyaç duyduğu tarihsel ve coğrafi yeri sağlayan gelişmenin özellikle dinin gerilemesi olduğu savunan Anderson, milliyetçiliğin ulus olmak için ihtiyaç duyulan birlik duygusunu ve tinsel ilkeyi yaratma sürecinde tarih yazımının ve eğitim mekanizmasının rolüne dikkat çekmiştir (Anderson, 2004, s.129). Milletleri ve milliyetçiliği toplumsal mühendislik ürünü olarak gören Marksist tarihçi Eric Hobsbawm ise modern çağda üretilmelerine rağmen bugünü 'tercih edilen' bir geçmişe bağlayan geleneklere- icat edilmiş gelenekler- dikkat çeker. Bu bağlamda öncelikle Fransa ve İngiltere gibi erken ulus-devletleri ele alan ve bu milletlerin icadının "doğal" olmadığını ifade eden Hobsbawm, zorunlu eğitimin gelenek icadındaki rolüne dikkat çekmiştir (Hobsbawm, 2006, s. 270-300).

\section{İdeoloji- İktidar- Eğitim İlişkisi}

Yukarıdaki yapılanmacı/modernist düşünürlerin de belirttiği gibi iktidarların ulusu ve ulus kimliğini icat ederken başvurduğu en etkili araçlardan biri eğitimdir. Her eğitim sistemi, belli bir eğitim politikası aracılığıyla toplumsal düzenin taleplerini karşılamaya çalışır. Bu süreçte bilgi, toplumsal değerlerle yoğrularak "yanlı" hale getirilir ve bu şekilde bilgiye meşruluk kazandırılır. Bilgiyi meşrulaştırma siyasal iktidar ve ideolojiyle yakından ilişkilidir (Gençkal Eroler, s.29)

Michael Billig'e göre, milletlerin, milli kimliklerin ve vatanların doğal kabul edilmesi milliyetçiliğin ideolojik karakteriyle ilişkilidir ve günlük hayatımızda düşünmeden sürdürdügümüz, doğal kabul ettiğimiz şeylerin aslında verili olmadığını fark etmek oldukça zordur. Bu sebeple icat edilmiş unsurları fark ederek milliyetçilikleri gerektiği gibi incelemek için yeniden üretim süreçlerini yani iktidar ilişkilerini incelemek gerekir. İktidar-eğitim ilişkisi üzerine düşünen Gramsci, hegemonya ile ideoloji arasında kurduğu ilişki ile eğitimin ideolojik işlevine yönelik önemli fikirler öne sürmüştür. Gramsci'ye göre sistemin gerçek gücü yönetici sınıfın şiddetinde veya devlet aygıtının baskı gücünde değil, yöneticilerin ‘dünya görüşünün' yönetilenler tarafından kabul edilmesinde yatar (Gramsci, 1970, s. 238). Dolayısıyla ona göre ideoloji, hakim sınıfın zor kullanmak durumunda kalmadan, rıza devşirmek suretiyle hegemonyasını tesis etmesine yarar ki okul, aile, medya, ordu gibi kurumlar rıza üreten yapılar olarak değerlendirilebilir.

Althusser ise "yeniden üretim” ile bir ekonomik sistemin kendi üretim şartlarını üretmesinin gerekliliğine vurgu yapar ve bunun da ancak gerekli insan tipinin üretilmesiyle mümkün olduğunu ifade eder. Ona göre devletin bu amaca hizmet eden iki türlü aygıtı vardır: baskı aygıtları ve ideolojik aygıtlar. Devletin baskı aygıtları polis, mahkemeler ve orduyu içerirken, devletin ideolojik aygıtları siyasi partiler, dini kurumlar, medya ve özellikle eğitimi içerir. Althusser'e göre gelişmiş kapitalist sistemlerde devletin en temel ideolojik aygıtı eğitimdir çünkü tüm toplumsal sınıfların çocuğunu anaokulundan 
itibaren alır ve etkiye en açık oldukları çağda yıllarca katıksız egemen ideolojiyle kaplanmış 'beceriler'i onların kafasına yerleştirir (Althusser, 2010, s.175-180).

Michel Foucault ise, bilgi ve iktidar arasındaki ilişkiye, iktidarın meşrulaştırılmasına ve 'doğruyu' üreten söylemlere odaklanır. Foucault'ya göre, iktidar devamlılığını sağlamak için varoluşunu meşrulaştıracak bir doğruluk rejimine ihtiyaç duyar. İktidar, gerçeklik söylemini kuran bu rejim olmadan işleyemez; eğitim de bu işlevin yerine getirilmesi noktasında iş görür. Eğitim siyasal iktidara kendi ilkelerini topluma dayatmanın kurumsal imkanını sunar. Bu yönüyle ideolojik bir aygıt olarak eğitim, kontrol toplumunun oluşumuna belli bir hayat nizamını zorla kabul ettirerek hizmet eder. Eğitim, siyasal aklın aracı olarak kontrol toplumunun devamlılığını amaçlamaktadır. Eğitim sürecinde öğrenilen bilgi iktidar tarafından üretilip kullanılması açısından araçsaldır. Eğitim sistemi, normalleştirme işleviyle siyasal iktidarın değerlerini mutlak doğrular olarak topluma sunar (Çetin, 2001, s.208).

Bourdieu da modern toplumlardaki sınıf, kültür ve iktidar arasındaki sıkı bağları irdeleme çabası içinde eğitime büyük bir önem atfetmiştir. Bourdieu, eğitim düzeylerindeki muazzam artışa rağmen servet, gelir ve statü eşitsizliklerinin çarpıcı boyutlarına dikkat çeker. Bourdieu'ya göre, iktidar eşitsizliklerinin ve ayrıcalıkların, farkında olunmadan ve kamusal bir direnişle karşılaşmadan nesilden nesile aktarılmasında eğitim sistemi önemli görevler üstlenir. Bourdieu’nun, Fransız yüksek öğrenim sisteminde yaptığı araştırmalara göre, bir yandan yüksek öğrenimde seçeneklerin artmasıyla birlikte eğitim alanında eskisine göre daha fazla firsat sunulmakta; diğer yandan yüksek öğrenim sistemi içerisinde sınıf temelli sosyal tabakalaşma pekiştirilmektedir (Swartz, 2013, s.272). Yani, Bourdieu'nin analizinde eğitim sistemi toplumsal sınıflar arasındaki güç ve ayrıcalık ilişkilerini pekiştirme işlevini görür.

\section{0 ve 21. Yüzyılda Demokrasi Modelleri}

Demokrasinin tanımı meselesi günümüzde halen güncelliğini koruyan bir tartışmadır. Böyle olduğu için de demokrasinin farklı tanımlarının yanında farklı modelleri de vardır. Demokrasi bir yönetim biçimi olarak günümüzde evrensele yakın bir kabul görse- hatta tam da bu sebeple- farklı ülkelerdeki birbirinden oldukça farklı örgütlenme biçimleri, kendilerini demokrasi olarak ifade etmişlerdir. Diğer yandan, siyaset felsefesinde Platon'a kadar uzanan bir akım da mevcuttur ki demokrasinin erdemlerinin yanında kusurlarının da bulunduğunu savunur. İşte farklı demokrasi modelleri temelde bu kusurlar ve erdemler ile ilgili tartışmalardan ortaya çıkmıştır.

İlk defa Antik Yunan'da MÖ 500'lü y1llarda ortaya çıkan demokrasi (demokratia) sözcüğünün etimolojik kökenine bakıldığında halkı ifade eden "demos" ile hükmetmek anlamına gelen "kratos" sözcüklerinin birleşmesiyle ortaya çıktı̆̆ 1 bilinir. Dolayısıyla demokrasi ifadesi en temel anlamıyla halkın yönetimi anlamına gelmektedir. Abraham Lincoln'ün ünlü demokrasi tanımına göre ise demokrasi, "halkın halk tarafindan halk için yönetimidir" (Lijpart, 1999, s.1). İşte söz konusu "halkın yönetimi"nin ne anlama geldiği, daha doğrusu nasıl ortaya çıktı̆̆ı, yurttaşların iradesinin çoğunun mu yoksa tümünün mü iradesinin aranması gerekliliği meseleleri farklı demokrasi modellerinin ortaya çıkmasına sebep olmuştur. Halkın yasama faaliyetini bizzat yerine getirdiği doğrudan demokrasinin günümüz çok nüfuslu ve modern toplumlarında mümkün olmaması sebebiyle temsili demokrasi içinde mümkün olan iki temel demokrasi modeli üzerinde durulması bu çalışmanın içeriği açısından anlamlıdır: çoğunlukçu ve çoğulcu model.

En tipik örneği İngiltere'deki Westminster modeli olan çoğunlukçu demokrasi esas itibariyle çoğunluğun hakimiyetini esas alır. Bu modelde, "halkın yönetimi" denildiğinde akla çoğunluğun yönetimi gelmektedir. Nitekim halk arasında çıkacak uyuşmazlıklarda kimin iradesine başvurulacağ sorusunun cevabı büyük ölçüde "halkın çoğunluğu" olmaktadır (Lijphart, 1996, s.11). Çoğulcu demokrasi anlayışı ise çoğunluğun yönetiminin bir antitezi değildir esasında. Fakat çoğunluğun yönetimi ile azınlıkta kalanlar arasında bir dengenin kurulması gerekliliğinin altını çizer. Zira 
çoğunluğun yönetme erki sınırsız değil bilakis azınlığın temel hakları ile sınırlıdır (Gözler, 2015, s.258). Çoğulcu demokrasi siyasal iktidarın çeşitli merkezler arasında paylaştırılmasını ve azınlığın haklarının korunmasını içerir. Zira çoğulcu demokrasi modeli toplumsal uzlaşıyı esas alarak toplumdaki farklı grupların özgür bir şekilde tartışarak kendilerini ifade etmelerini ve nihayet siyasal olarak temsil edilmelerini öngörür. Sadece iktidara oy veren çoğunluğun değil, iktidara oy vermeyen azınlığın da haklarını savunan, en azından muhalefet yapabilmesine imkan tanıyan demokrasi anlayışıdır. Katılımcı demokrasi anlayışı gereğince, iktidar dışında bulunan grupların, siyasal alana katılma hakkının bulunduğu ve iktidarın yetkilerinin sınırlandırıldığı sistemdir.

20. yüzyıl başlarında dünyada geçerli olan klasik demokrasi anlayışı, azınlık gruplara çoğunluk grup ile eşit haklar sağlama yolunda ayrımcılı̆̆ın önlenmesi politikasına başvurulmasını öngörür. Her türlü hukuksal eşitliğin sağlandığı ama sınıf farklarının dikkate alınmadığı bu demokrasi türünde egemen sınıf oyunun kurallarını devlet adına koyar ya da bugün örnekleri görüleceği gibi azınlıkları eritmeye girişen ve bunu da "millet adına" konuşan belli bir etnik grubun (çoğunluk grubunun) yönetiminde yapan bir devlet türü, yani ulus-devlet vardır. Alt sınıfları ve alt kimlikleri görmezden gelen bu demokrasi anlayışlarının demokratik olmadığını ifade eden Oran, azınlıklara yönelik kanun önünde eşitliğin ötesinde azınlıklara pozitif haklar verilmesini öngören "azınlıkların korunması" anlayışının yerleşmesi gerekliliğinin altını çizer. Zira bu anlayış 21. yüzyıl çağdaş demokrasisini yansıtır. Yani tarihsel olarak bakıldığında 19. Yüzyılda ve 20. yüzyılın başında "çoğunluğun yönetimi" olarak tanımlanan demokrasinin, 21. yüzyıldaki tanımını kısaca "alt kimliklere saygı" şeklinde ifade etmek mümkündür. Bununla bağlantılı olarak söz konusu iki dönemdeki farklılıklara ilişkin devlet politikaları değişmektedir. 19 ve 20.yüzyılın klasik demokrasi anlayışında asimilasyon ve nüfus mübadelesinden etnik soykırıma uzanan etnik temizlik bir politika tercihi olarak meşru görülebilirken, 21. Yüzyıl çağdaş demokrasisinde bu uygulamalar kabul görmez ve farklı kimlikleri tanınmasına dayanan uzlaşının sağlanması esastır. Özetle, 20.yüzyıl klasik demokrasisinin çoğunlukçu demokrasi modeline, 21. Yüzyıl çağdaş demokrasisinin ise çoğulcu modele dayandığı söylenebilir.

\section{Illliberal Demokrasilerin Yükselişi}

"İlliberal (otoriter) demokrasi” kavramı, günümüzde özellikle az gelişmiş ülkelerdeki demokrasi tartışmalarında kullanılan ve yaygınlaşan bir kavramdır. Demokrasinin çelişkili bir seyir izlediği durumları açıklamada işlevsel olan bu kavram, genellikle serbest seçimlerin var olmasına rağmen yurttaşlık haklarının giderek sınırlandığı durumları tarif etmek için kullanılır. Yani, varlığını demokratik seçimlere borçlu olan iktidarların zaman içinde demokratik hakları kısıtlamaya çalışması eğilimi ortaya çıkmaktadır. Söz konusu eğilim, seçim sonucunda iktidara gelen hükümetin mutlak iktidara sahip olduğu inancına kapılarak hukuka ve kuvvetler ayrıllğı ilkesine aykırı bir biçimde bütün gücü elinde toplamaya ve muhalefete firsat vermemeye çalışması şeklinde kendini belli eder. Günümüzde "illiberal demokrasi" veya "demokratik otoriteryenizm şeklinde tabir edilen ve yaygınlaşan bu rejimler demokrasiyi adeta iktidarın seçimle belirlenmesi ilkesine indirgemiş görünmektedir. Söz konusu anlayış demokrasiden "çoğunluk despotizmine" dönüşerek çoğunlukçu demokrasi anlayışının yozlaştırılması sonucunda ortaya çıkmaktadır.

Tam da bu dönüşüm ihtimali sebebiyle pek çok yazar çoğunlukçu demokrasi modelinin sakıncalarına dikkat çekmiştir. Örneğin, Lijphart'a göre, çoğunlukçu demokrasi modeli az çok homojen toplumlarda işlese de, etnik köken, rrk, din, dil, kültür, ideoloji vb. açılardan bölünmüş ve her grubun kendi partisi, çıkar grubu ve iletişim araçlarına sahip olduğu toplumlarda ciddi tehlikeler yaratır (Lijphart, 1996, s.12-13). Robert A. Dahl da, olası sakıncalarına dikkat çektikten sonra, çoğunlukçu demokrasinin sağlıklı bir şekilde işlemesini üç özel koşulun bulunması ile ilişkilendirmiştir. Buna göre, çoğunlukçu demokrasi modelinin ilk koşulu, toplumun türdeş-homojen olmasıdır. İkinci koşulu azınlıkların kemikleşmemiş olması olarak sayan Dahl, üçüncü olarak da azınlıktaki grupların haklarının korunması konusunda sağlam güvencelere sahip olması gerektiğini belirtmektedir. Yine de Dahl'a göre, demokrasinin sağlıklı bir biçimde işleyebilmesi için çoğunlukçuluğun sınırlanması daha uygun bir 
yaklaşımdır (Dahl, 1993, s.203-204). Giovanni Sartori, çoğunlukçu demokrasi ile çoğunluk despotizmi arasındaki ayrımın, muhalefetin sağlam güvencelere sahip olup olmadığına, muhalefetin baskı altına alınıp alınmadığına bakılarak çizilebileceğini belirtmektedir. Sartori, "seçimli zorbalık" olarak nitelediği çoğunluk despotizmine yol açan temel bozukluğu ise, kuvvetler ayrılığı ile sinırlandırılmamış bir hükümetin, sınırsız iktidar kullanımı olarak görmektedir (Sartori, 1996, s.143-149).

$\mathrm{Bu}$ fikirlerden de yola çıkarak varılabilecek en temel sonuç, çoğunlukçu demokrasi ile çoğunluğun mutlak iradesi şeklinde ifade edilebilecek olan çoğunluk despotizminin farklı şeyler olduğudur. Dolayısıyla çoğunlukçu demokrasinin çoğunluk despotizmine dönüşmesinin alt yapısını toplumun ortak çıkarını temsil eden milli iradenin çoğunluğun iradesine indirgenmesi yanlışı yatmaktadır. Milli irade kavramı, J.J. Rousseau'nun ortaya attığı "genel istenç" ile ilişkilendirilerek 18. Yüzyıla kadar geri götürülebilir. Toplumdaki bireylerin tüm haklarını devrettikleri- karşılığında doğa durumundan çıarak uygar hak ve özgürlüklere sahip oldukları- genel istenç Rousseau'ya göre, kişisel çıkarların toplamı olan herkesin çıkarı değil, ortak çıkardır. Yani genel istenç, kişisel istençlerin basit bir toplamından ibaret olmamakla birlikte, çoğunluk istenci de değildir. Ona göre bir kararda oy çokluğu sağlanmış olabilir ama yine de o karar toplumun çıarına olmayabilir. Öte yandan çoğunluğun katılmadığı bir görüş toplumun çıkarına dolayısıyla genel istence uygun olabilir. Hatta tek bir kimsenin bir görüşü bile toplumsal çıkara uygunsa, genel istenç demektir (Şenel, s.395-396). Yani Rousseau'ya göre, genel istencin ortaya çıkması için oy çokluğu ya da oybirliği zorunlu değildir, genel istenç ortak yarardır. Dolayısıyla genel istenci temsil edip kullanan egemen, tek bir kişi, bir azınlık, çoğunluk ya da toplumun tamamı olabilir. Bu ifadelerden anlaşılabileceği gibi Rousseau'nun genel istenç kavramı hem demokratik hem de otoriter yorumlara elverişli olan, çeşitli yönetim biçimlerine uyan esnek bir niteliktedir. Hem Fransız devriminin burjuva demokratik düşünürlerini hem de otoriter bir devlet anlayışı geliştiren Hegel'i etkilemiş olması bunun bir göstergesidir. Hatta Lenin, Hitler, Mussolini gibi faşist parti önderleri de Rousseau'nun kuramlarından yararlanarak genel istenci temsil ettiklerini iddia etmişlerdir. Diğer yandan, Rousseau'nun egemenliğin koşulsuz halkın olduğu ilkesi ve bir yönetim biçiminin çoğunluğun oyunu alıp almadığına bakılarak değil, tüm toplumun yararı ölçütüne göre değerlendirilmesi gereğine değinmesi demokrasi yolunda atılmış önemli bir adımdır. Zira çoğunluk da neticede toplumdaki gruplardan- en büyüğü olsa da- bir tanesidir ve toplumun tamamını yansıtmamaktadır. Bunun yanında çoğunluğun da yanılabileceği ya da adil olmayan bir yönelim içinde olabileceği de olasılık dahilindedir. İşte milli iradeyi çoğunluğun iradesi ile özdeşleştiren yaklaşımın temel problemi bu olasılı̆̆ 1 göz ardı ederek farklı düşünce, değer ve çıkarları baskı altında tutma ya da yok sayma eğilimidir.

\section{Eğitim Politikaları ve Demokrasi}

Eğitim politikaları, siyasal iktidarın gücünü yeniden üretme ve bu doğrultuda ulus kimliği inşasında etkili bir araç olduğundan, bir ülkede demokrasinin durumu eğitim politikalarına bakarak anlaşılabilir. Zira eğitim politikaları iktidarların elinde, onların demokrasi ile kurduğu ilişki ile uyumlu olarak şekillenir. Özellikle de tarih ders kitaplarında yer alan anlatı, dönemin siyasal söyleminin adeta bir kopyasıdır.

21.yüzyılda çoğulculuğu esas alan çağdaş demokrasi anlayışının 20.yüzyılın çoğunlukçu klasik demokrasi anlayışından üstün olduğunu söyleyebilirsek de, 21. yüzyılda paradoksal biçimde yeni bir otoriterliğin yükseldiği görülür. Söz konusu otoriterlik, çoğunlukçu demokrasi modelinin yozlaşması sonucunda ortaya çıkan bir durumdur. Bu durumda, iktidar kanadında çoğunluğun oyunu alarak iktidara gelmeyi tüm topluma hakim olmak sayan bir algı söz konusudur. Bu algı, muhalefeti hoş karşılamayan, dahası bunun "milli irade" karşıtllğg sayarak "biz" sınırlarını daraltan ve "öteki" sınırlarını genişleten bir otoriter-popülist yönelime yol açmaktadır. Söz konusu yönelime örnek olarak Rusya Federasyonu'nun Viladimir Putin önderliğinde kavramsallaştırılan Putinizm ya da Macaristan'daki Victor Orban yönetimi gösterilebilir. Rusya'daki postmodern otoriter yönetimin mimarı kabul edilen Rusya Devlet Başkanı Vladimir Putin'in üst düzey danışmalarından Vladislav Surkov, "gözetimli 
demokrasi” olarak tanımladı̆̆ Putinizm'i dünyada geleceğin ideolojisi olacağını iddia etmiştir (BBC, 12.02.2019).

Söz konusu siyasi eğilimleri eğitim politikaları üzerinden okumak mümkündür. Rusya örneğinde, Sovyetler Birliği’nin yıkılmasının ardından 1990'l y yllarda oluşturulan görece çoğulcu tarih anlatımının, 2000'li yıllar Putin yönetimi altında giderek artan oranlarda yerini tarih eğitiminin Rus kimliğinin inşasının ve ulusal ideolojik dönüşümünün aracı olarak kullanılmaya başlanmasına bıraktığı görülür (Balta ve Demir, 2016, s.8). Kendisini muhafazakar, dindar ve gelenekçi olarak tanımlayan Orban önderliğindeki Macar hükümeti, aşırı sağ eğilim ve muhalefetin baskılanması temelinde uyguladığı anti-demokratik uygulamaları ile Avrupa içinde yoğun tepki çekmektedir. Söz konusu antidemokratik uygulamaların eğitimdeki yansıması da milliyetçi militarist eğitim anlayışının yeniden canlandırılmasıdır. Tüm eski komünist rejimlerde olduğu gibi Macaristan'da da 1989'a kadar askeri eğitim kültürü mevcuttu. Fakat 1989' da demir perdenin yıkılmasının ardından, Macaristan askeri eğitim kültürüne son vererek eğitimi demokratikleştiren ülkelerin başında geliyordu. Fakat Orban yönetiminde, söz konusu eğitim kültürünün Milli Güvenlik derslerinin yeniden müfradata alınması suretiyle yeniden diriltilmeye çalışılması söz konusudur. Nitekim 2017 yılında çıkartılan bir Bakanlar Kurulu kararı ile "Vatanperver Savunma Eğitim Programı" adı altında bir ders planı hazırlanması talimatı verildi, gençlerin "ülkelerini her daim savunmaya hazır vatanperver nesiller" olarak yetiştirilmesinin amaçlandığ 1 vurgulandı. Dahası bunun bir dersten öte "eğitim konsepti" olduğu söylenerek tüm derslerde öğrencilere milli güvenlik bilincinin aşılanması planlandığı belirtildi (DW, 14.08.2017).

\section{Sonuç}

Ulus-kimliği veya modern vatandaşlık kavramı, iktidarın var olan sosyal düzeni kendi ihtiyaçları doğrultusunda yeniden ürettiği ulus-inşa süreçleriyle bağlantılıdır. Tam da bu noktada, ulus kimliğin iktidar ile ilişkisi ortaya çıkar: dili, kültürü ve eğitimi düzenleme yetisini elinde bulunduran iktidar, ulus kimliğini yaratır ve gerektiğinde, koşullara göre, dönüştürür.

Eğitim politikaları ise siyasal iktidara ulus kimliğini kendi iktidarı doğrultusunda inşa etme ve dönüştürme imkanını ideolojik bir araçtır. Tam da bu sebeple ülkede demokrasinin durumu eğitim politikalarına bakarak anlaşılabilir. Zira eğitim politikaları iktidarların elinde, onların demokrasi ile kurduğu ilişki ile uyumlu olarak şekillenir.

Demokrasinin çoğunluğun despotizmine dönüşmesini engelleyebilmek için, "çoğulcu demokrasi" modelinin "çoğunlukçu demokrasi" modeline göre daha gelişmiş ve daha güvenli bir model olduğu öne sürülebilir. Zira çoğulcu model, tüm toplumu ilgilendiren konularda basit çoğunluk yerine daha geniş uzlaşılar arayarak ve azınlıktaki grupların da desteğini kazanarak demokrasinin meşruiyetini güçlendirir.

Tarihsel olarak 21.yüzyılda çoğulculuğu esas alan çağdaş demokrasi anlayışının 20.yüzyılın çoğunlukçu klasik demokrasi anlayışından üstün olduğunu söyleyebilirsek de, 21. yüzyılda paradoksal biçimde yeni bir otoriterliğin yükseldiği görülür. Söz konusu yeni otoriterlik, Rusya ve Macaristan örneklerinde askeri eğitim kültürünün yeniden canlandırılması şeklinde kendisini belli eder.

\section{KAYNAKÇA}

Althusser, Louis. İdeoloji ve Devletin İdeolojik Aygıtları. İthaki Yayınları, 2010.

Anderson, Benedict. Hayali Cemaatler. Çev.: İskender Savaşır, Metis Yayınları, İstanbul, 2004.

Balta, Evren ve Süheyla Demir. "Tarih, Kimlik ve Dış Politika: Rusya Federasyonu Güncel Tarih Ders Kitaplarında Osmanl1-Türk İmajı”. Bilig, Kış 2016, Sayı: 76. 
BBC Türkçe, "Putin'in danışmanı Surkov: Geleceğin ideolojisi Putinizm olacak, herkes buna alışmalı" https://www.bbc.com/turkce/haberler-dunya-47209500, 12.02.2019, erişim tarihi: 24.06.2019.

Brubaker, Rogers. Citizenship and Nationhood in France and Germany. Cambridge, Harvard University Press, 1992.

Çetin, Halis. "Devlet, İdeoloji ve Eğitim". Cumhuriyet Üniversitesi Sosyal Bilimler Dergisi. 25(2), 2001.

Dahl, Robert A. Demokrasi ve Eleştirileri. Çev. L. Köker. Yetkin Yayınları. Ankara, 1993.

Delanty, Gerard ve Patrick O’Mahony. Nationalism and Social Theory. London: Sage, 2002.

Deutsche Welle, "Macar okulları askerileştiriliyor", 14.08.2017, https://www.dw.com/tr/macarokulları-askerileştiriliyor/a-40087629, erişim tarihi: 24.06.2019.

Fiori, Giuseppe. Antonio Gramsci: Life of a Revolutionary. Londra: New Left Books, 1970.

Gellner, Ernest. Uluslar ve Ulusçuluk, Çev.: Günay Göksu Özdoğan ve Büşra Ersanlı. Hil Yayın. 2013.

Gençkal Eroler, Elif. “Dindar Nesil Yetiştirmek: Türkiye’nin Eğitim Politikalarında Ulus ve Vatandaş İnşası (2002-2016). İletişim Yayınları. İstanbul, 2019.

Giovanni, Sartori. Demokrasi Teorisine Geri Dönüş. Çev. T. Karamustafaoğlu - M. Turhan. Yetkin Yayınları. Ankara, 1996.

Gözler, Kemal. Anayasa Hukukunun Genel Esasları. 7. Basım, Ekin Basımevi. Bursa, 2015.

Güvenç, Bozkurt. "Tarihi Perspektifte Kimlik Sorunu Özdeşimlerini Belirleyen Bazı Etkenler”, Tarih Eğitimi ve Tarihte "Öteki” Sorunu. 2. Uluslararası Tarih Kongresi Tebliğler. Tarih Vakfı Yurt Yayınları. İstanbul, Ekim 2014.

Hobsbawm, Eric J. Milletler ve Milliyetçilik: Program, Mit, Gerçeklik. Ayrıntı Yayınları. İstanbul, 2006.

Lijphart, Arend. Çağdaş Demokrasiler (Yirmi Bir Ülkede Çoğunlukçu ve Oydaşmacı Yönetim Örüntüleri). Çev: E. Özbudun, E. Onulduran. Yetkin Yayınları. Ankara.

Lijphart, Arend. Patterns of Democracy (Government Forms and Performance in Thirty-Six Countries). First Edition. Yale University Press. New Haven and London, 1999.

Oran, Baskın. Etnik ve Dinsel Azınlıklar: Tarih, Teori, Hukuk, Türkiye. Literatür Yayınları. İstanbul, 2018.

Özdoğan, Günay Göksu, Füsun Üstel, Karin Karakaşl1, Ferhat Kentel. Türkiye'de Ermeniler: CemaatBirey, Yurttaş, İstanbul Bilgi Üniversitesi Yayınları. 1. Baskı, İstanbul, Haziran, 2009.

Özkırımlı, Umut. "Türkiye'de Gayriresmi ve Popüler Milliyetçilik", Modern Türkiye'de Siyasi Düşünce, Cilt 4. Milliyetçilik, Ed. Tanıl Bora ve Murat Gültekin. İletişim Yayınları. 4. Baskı, 2009.

Özkırımlı, Umut. Milliyetçilik Üzerine Güncel Tartışmalar: Eleştirel Bir Müdahale. İstanbul Bilgi Üniversitesi Yayınları, İstanbul, Ekim 2010.

Robertson, R. 'Glocalization: Time-spaceandhomogeneity-homogeneity'. In M. Featherstone, S. Lashand R. Robertson (eds). Global Modernities. 25-44. London: Sage., 1995.

Swartz, David. Kültür ve İktidar: Pierre Bourdieu'nün Sosyolojisi, İletişim Yayınları, 2013. 
Şenel, Alaeddin. Siyasal Düşünceler Tarihi: Tarihöncesinde İlkçağda Ortaçağda ve Yeniçağda Toplum ve Siyasal Düşünüş. Bilim ve Sanat Yayınları. Ankara 2013.

Tekeli, İlhan. "Tarihyazıcıllı̆ı ve Öteki Kavramı Üzerine Düşünceler". Tarih Eğitimi ve Tarihte "Öteki" Sorunu. 2. Uluslararası Tarih Kongresi Tebliğler. Tarih Vakfı Yurt Yayınları. İstanbul, Ekim 2014. 